IZA DP No. 8936

Heterogeneity in Spousal Matching Models

Jason Fletcher

Norma Padrón

March 2015

Forschungsinstitut

zur Zukunft der Arbeit

Institute for the Study

of Labor 


\title{
Heterogeneity in Spousal Matching Models
}

\author{
Jason Fletcher \\ University of Wisconsin \\ and IZA \\ Norma Padrón \\ HPM, Yale University \\ Discussion Paper No. 8936
March 2015 \\ IZA \\ P.O. Box 7240 \\ 53072 Bonn \\ Germany \\ Phone: +49-228-3894-0 \\ Fax: +49-228-3894-180 \\ E-mail: iza@iza.org
}

Any opinions expressed here are those of the author(s) and not those of IZA. Research published in this series may include views on policy, but the institute itself takes no institutional policy positions. The IZA research network is committed to the IZA Guiding Principles of Research Integrity.

The Institute for the Study of Labor (IZA) in Bonn is a local and virtual international research center and a place of communication between science, politics and business. IZA is an independent nonprofit organization supported by Deutsche Post Foundation. The center is associated with the University of Bonn and offers a stimulating research environment through its international network, workshops and conferences, data service, project support, research visits and doctoral program. IZA engages in (i) original and internationally competitive research in all fields of labor economics, (ii) development of policy concepts, and (iii) dissemination of research results and concepts to the interested public.

IZA Discussion Papers often represent preliminary work and are circulated to encourage discussion. Citation of such a paper should account for its provisional character. A revised version may be available directly from the author. 
IZA Discussion Paper No. 8936

March 2015

\section{ABSTRACT}

\section{Heterogeneity in Spousal Matching Models ${ }^{1}$}

An important paper by Chiappori et al. (2012) has proposed an elegant and parsimonious model of spousal matching over multi-dimensional characteristics. Importantly, the model suggests specific testable assumptions that allow researchers to uncover marginal rates of substitution (MRS) between spousal traits, and the authors use the Panel Study of Income Dynamics to show that the model is not rejected by the data. In this paper, we extend the analysis to two additional representative samples of US couples and find in each case, the data reject the MRS implication of the model.

JEL Classification: D1, J1, C78

Keywords: marriage market, marriage matching, multidimensional matching, trade-offs, spouses, body mass index (BMI), education

Corresponding author:

Jason Fletcher

University of Wisconsin

1180 Observatory Drive

Madison WI 53706

USA

E-mail: jmfletcher@wisc.edu

\footnotetext{
${ }^{1}$ This research uses data from Add Health, a program project directed by Kathleen Mullan Harris and designed by J. Richard Udry, Peter S. Bearman, and Kathleen Mullan Harris at the University of North Carolina at Chapel Hill, and funded by grant P01-HD31921 from the Eunice Kennedy Shriver National Institute of Child Health and Human Development, with cooperative funding from 23 other federal agencies and foundations. Special acknowledgment is due Ronald R. Rindfuss and Barbara Entwisle for assistance in the original design. Information on how to obtain the Add Health data files is available on the Add Health website (http://www.cpc.unc.edu/addhealth). No direct support was received from grant P01-HD31921 for this analysis.
} 


\section{Introduction}

Despite an extensive literature on the effects of marriage on a wide variety of outcomes, most of the models focus on a single characteristic to investigate the matching process. Hence, empirical studies have mostly investigated matching in marriage on a case-by-case basis using characteristics such as race, income, wages and education (Choo and Siow 2006); (Galichon and Salanié 2011) and, often assume a transferable utility context to explain the observed assortative matching patterns.

Transferable utility has some appealing aggregation properties, however as highlighted by Chiappori et al. (2012), there are costly disadvantages to this assumption. In particular, in transferable utility the 'group' behaves as a single decision-maker, hence the efficient decision at the group level in this framework does not depend on the distribution of Pareto weights. In the context of marriage matching it means that the matching process is unidimensional despite overwhelming empirical evidence to the contrary (Hitsch, Hortaçsu et al. 2010), (Oreffice and Quintana-Domeque 2012). Overall, although the foundation for a conceptual theoretical framework of multidimensional matching exists (or can be generalized from the properties of unidimensional models), it has very rarely been explored empirically.

Chiappori et al. (2012) advance this literature by testing empirically the implications of a theoretical framework of multi-dimensional matching. Their multidimensional matching process operates via a single index of "attractiveness" that 
each individual in the marriage market has, and assumes separability between partner indices. Specifically, the assumptions of their model suggest a specific test that can uncover the marginal rates of substitution between spousal straits and the authors use PSID data on spousal educational attainment and body-mass index to show the model is not rejected by the data.

This paper replicates their analyses using two nationally representative US datasets with information on the same spousal attributes, education and body mass index. Overall, our results reject the empirical implications of the framework, casting doubt on the use of the separability assumption in a broad class of matching models.

\section{Data}

We first use the National Longitudinal Survey of Adolescent Health (Add Health). The Add Health data is a nationally representative study of U.S high school students with four waves of data. Wave I sampled 20,745 students in grades 7-12 in the 1994-1995 academic year (ages 12-18). The sample used in our analyses comes from the Add Health Romantic Pair data, a restricted access subsample which collected information from 1,507 married, cohabitating, and dating partners (about one third, 500, each) in wave III when respondents were between the ages of 18-24. Wave III respondents of $18+$ years of age who reported having a current relationship of three months or more duration with opposite-sex partners were asked to recruit their partners for participation in the wave III interview. Hence the Romantic Pairs data contains information about each partner in the relationship reported by each individual. The measures we explore using the Add Health data, are BMI, a measure of physical attractiveness, and educational attainment, a measure of financial attractiveness. 
In addition, we replicate the analysis in Chiappori et al. (2012) using the National Health and Nutrition Examination Survey (NHANES) survey. NHANES data is collected through survey questionnaires and physical examinations by health technicians and hence is less prone to measurement error. These data are also gathered from each individual so that, unlike the PSID, it is not only one partner reporting the measures of both partners. Our measure in this set of analyses is BMI, and for socioeconomic attractiveness, years of education.

\section{Theoretical framework and Empirical Analysis Setup}

The objective of this exercise is to investigate the role of relative attractiveness in romantic ex-post pairings in order to understand the process and tradeoffs behind the matching patterns observed in the data. The advantage of the theoretical model in Chiappori et al. (2012) is that it provides a tractable framework with testable implications that can be identified irrespective of the matching game that is played between the agents.

There is however, a key assumption in Chiappori et al. (2012): The 'attractiveness' of male i (resp. female $j$ ) on the marriage market is fully summarized by a one-dimensional index ${ }^{2}$, and this index is weakly separable in the observable characteristics. The assumptions of a single index and (weak) separability have in practice an implication: that the (ordinal) value of the "attractiveness index" is universal; hence any two people with the same index are identical for matching purposes to everyone else. In what follows we discuss the theoretical model and testable implications in Chiappori et al. (2012) and outline the empirical strategy derived from their model.

\footnotetext{
${ }^{2}$ We use the same notation as in Chiappori et al. (2012) throughout.
} 
Consider that a male in the marriage market is characterized by a vector $X_{i}=$ $\left(X_{i}^{1}, \ldots, X_{i}^{k}\right)$ of observable attributes and some vector of unobservable characteristics $\varepsilon_{i}$. Similarly, a female in the marriage market is characterized by a vector $Y_{j}=\left(Y_{j}^{1}, \ldots, Y_{j}^{k}\right)$ of observable characteristics and a vector $\eta_{j}$ of unobservable characteristics (both vectors of unobservables are iid).

As in Chiappori et al. (2012), the 'indices of attractiveness' can be expressed as:

$$
\begin{aligned}
& \text { Male attractiveness index: } I_{i}=i\left(I\left(X_{i}^{1}, \ldots, X_{i}^{K}\right), \varepsilon_{i}\right) \\
& \text { Female attractiveness index: } J_{j}=j\left(J\left(Y_{j}^{1}, \ldots, Y_{j}^{L}\right), \eta_{j}\right)
\end{aligned}
$$

If we observe the marital matching pattern in the population, which is the joint density of observable characteristics:

$$
d \mu\left(X_{i}^{1}, \ldots, X_{i}^{K}, Y_{j}^{1}, \ldots, Y_{j}^{L}\right)=d v\left[I\left(X_{i}^{1}, \ldots, X_{i}^{K}\right), J\left(Y_{j}^{1}, \ldots, Y_{j}^{L}\right)\right]
$$

For some measure $d v$. Even though there is multidimensionality (because each index is composed of multiple observable characteristics or dimensions), the conditional distribution of the vector of observable characteristics of a female in the marriage market $\left(Y_{j}^{1}, \ldots, Y_{j}^{L}\right)$, given the vector of observable characteristics of a male $\left(X_{i}^{1}, \ldots, X_{i}^{K}\right)$, only depends on the value of the subindex of male attractiveness $I\left(X_{i}^{1}, \ldots, X_{i}^{K}\right)$ (composed only of observable characteristics). This is by construction and, again, does not depend on any specific matching game.

It also follows that for any male, two women $j$ and $j$ ' with different profiles of observable characteristics $\left(Y_{j}^{1}, \ldots, Y_{j}^{L}\right)$ and $\left(Y_{j^{\prime}}^{1}, \ldots, Y_{j^{\prime}}^{L}\right)$ but identical indices $J_{j}=J_{j^{\prime}}$ are equally attractive in the marriage market. More formally, the expected value of the kth characteristic of the wife, conditional on the vector of characteristics of the husband has the form: 


$$
E\left[Y^{s} \mid X_{i}^{1}, \ldots, X_{i}^{K}\right]=\phi_{s}\left[I\left(X_{i}^{1}, \ldots, X_{i}^{K}\right)\right]
$$

With data on 'matched partners' we can recover the attractiveness indices up to some transform $(\phi)$. This suggests that the tradeoff between various spousal characteristics can be recovered, and we can (ordinally) identify the attractiveness indices to construct "iso-attractiveness" profiles which can be defined as:

$$
\begin{aligned}
& \text { For men: } i\left(I\left(X_{i}^{1}, \ldots, X_{i}^{K}\right), \varepsilon_{i}\right)=C \\
& \text { And for women: }\left(J\left(Y_{j}^{1}, \ldots, Y_{j}^{L}\right), \eta_{j}\right)=C^{\prime}
\end{aligned}
$$

Where $C$ and $C^{\prime}$ are constants. Furthermore, assuming $I$ and $J$ to be differentiable, the marginal rate of substitution, MRS, between characteristics $n$ and $m$ can be defined for male $i$ as:

$$
M R S_{i}^{m, n}=\frac{\partial I / \partial X^{n}}{\partial I / \partial X^{m}}
$$

Taking the partials at $\left(X_{i}^{1}, \ldots, X_{i}^{K}\right)$ and from equation (3), the above MRSs are given by

$$
\frac{\partial I / \partial X^{n}}{\partial I / \partial X^{m}}=\frac{\partial E\left[Y^{s} \mid X_{i}^{1}, \ldots, X_{i}^{K}\right] / \partial X^{n}}{\partial E\left[Y^{s} \mid X_{i}^{1}, \ldots, X_{i}^{K}\right] / \partial X^{m}}=\frac{f_{n}}{f_{m}}
$$

which are exactly identified. Since the left-hand side does not depend on $s$, neither does the right-hand side, which generated over-identifying restrictions.

Taking the model to the data requires us to specify a functional form. As in (Hitsch, Hortaçsu et al. 2010) and (Chiappori, Oreffice et al. 2012), we assume the functions $I$ and $J$ are linear:

$$
I\left(X_{i}^{1}, \ldots, X_{i}^{K}\right)=\sum_{k} f_{k} X_{i}^{k}
$$




$$
J\left(Y_{j}^{1}, \ldots, Y_{j}^{L}\right)=\sum_{l} g_{i} Y_{j}^{l}
$$

As discussed above, the distribution of any female characteristic conditional on the husband's profile of observable characteristics only depends on his attractiveness index. So, the coefficients of regressing the kth male attribute over the wife's profile should be proportional across the various regressions:

$$
X_{j}^{k}=\sum_{n} \gamma_{n}^{k} Y_{j}^{n}+\eta_{j}^{k}
$$

The random term $\eta_{j}^{k}$ captures unobserved heterogeneity and is correlated across $k$. In our analyses, we estimate (8) simultaneously for all characteristics $k$ via SeeminglyUnrelated-Regression (SUR). As in Chiappori et al. (2012), given the linear functional form specified for the indices, the MRS ${ }^{\mathrm{m}, \mathrm{n}}$ should not vary across characteristics $k$.

\section{Results}

In Table 1 we show the summary statistics for the variables in the Add Health sample, and for the variables from the NHANES sample. As expected, the mean age of respondents is lower among Add Health respondents ( $\sim 23$ for men and $\sim 21$ for women) than individuals in the NHANES ( $\sim 1$ men and $\sim 48$ women), and lie between the PSID sample used by Chiappori et al. (2012) ( 39 men and 37 women). Across all of our estimations we include controls for age, ethnicity and race.

Table 2 presents the regression of wife's characteristics on husband's characteristics, and of husband's characteristics on wife's characteristics. As expected (and similar to the estimates by Chiappori), the wife's BMI is negatively associated with husband's education (-.699), and positively associated with husband's BMI (.290). Wife's education exhibits the opposite pattern. In contrast to Chiappori et al's findings, our estimates of 
the MRS (the ratio of the coefficients) are not statistically significant, although they are of the same (negative) sign. As in their study, the proportionality test is not rejected (pvalue $=.966$ ). Numerically, the point estimate of the coefficient of husband's education to his BMI, a value of -2.41 implies that a 1 unit increase in BMI can be compensated by 2.41 years of schooling.

Table 2 also shows the results for the regression of husband's on wife's characteristics. As above, there is a positive association of husband's BMI and wife's BMI (.205), and there is a similar pattern on education as before. Here too, the coefficients of the MRS (ratio of the coefficients) are not statistically significant, and in this case we do reject the proportionality constraint, so that the restriction to identify the MRS is not met, p-value $=.0025$. This last result suggests the data reject the implication of the model. Unlike the Chiappori et al. results, the Add Health data does not suggest that more educated women marry husbands with lower BMIs than women with lower education levels

Table 3 replicates our results in a second sample - the NHANES. Here, when we present the regression of the wife's on husband's characteristics, we see that the wife's BMI is negatively associated with husband's years of education but that the wife's education is unrelated to husband's BMI, which is consistent with the results from Add Health in Table 2 but again inconsistent with the Chiappori et al. findings. Again, we show a rejection of the tests of equality of MRS across traits in one of the two cases (pvalue $>$. and $\mathrm{p}$-value=.08). Like the results from the Add Health sample (and arguably for the Chiappori et al. paper), the ratios are quite different in magnitude across specifications, suggesting that a failure to reject equality (in Chiappori and in some cases 
in our results) is likely a lack of power and small sample sizes rather than a statement about the similarity of the MRS.

\section{Conclusions}

In this study we extend the empirical exercise derived from the theoretical model of multidimensional matching in the marriage market developed in Chiappori et al. (2012). Our aim is to identify the existence of a marginal rate of substitution across traits that may characterize tradeoffs between physical and socioeconomic attractiveness in romantic matching.

We used two large, nationally representative datasets with measures reported by each individual in the romantic pair. In our estimations, our samples are larger than those used by Chiappori et al. (2012), which allows more precision in our estimates. The rejection of the equality of the ratios of the coefficients of trait (the identifying restriction for the marginal rate of substitution derived from the theoretical model) would suggest that the marginal rates of substitution are not reliably recoverable in their framework, and highlights that the assumption of a single index of attractiveness in the marriage market, and separability of spousal traits between spouses may not fully reflect the underlying process generating the data. 
Table 1. Descriptive Statistics of Main Variables in Add Health Data and NHANES

\begin{tabular}{|c|c|c|c|c|c|c|c|c|c|c|c|}
\hline \multicolumn{6}{|c|}{ Add Health Data } & \multicolumn{6}{|c|}{ NHANES Data } \\
\hline & Obs & Mean & Std.Dev & Min & Max & & Obs & Mean & Std.Dev & Min & Max \\
\hline$\stackrel{\text { Husband's }}{\text { Characteristics }}$ & & & & & & $\stackrel{\text { Husband's }}{\text { Characteristics }}$ & & & & & \\
\hline Education & 1,503 & 12.74 & 1.99 & 7 & 21 & $\begin{array}{c}\text { Years of } \\
\text { Education }\end{array}$ & 2,741 & 11.14 & 4.08 & 0 & 17 \\
\hline Age & 1,504 & 23.47 & 3.3 & 18 & 43 & BMI & 2,518 & 27.14 & 4.62 & 14.4 & 63.3 \\
\hline $\begin{array}{c}\text { Maternal } \\
\text { years of } \\
\text { Education }\end{array}$ & 1,486 & 12.59 & 2.55 & 0 & 17 & Age & 2,761 & 51.1 & 18.61 & 18 & 90 \\
\hline White & 1,504 & 0.6 & 0.49 & 0 & 1 & White & 2,761 & 0.55 & 0.5 & 0 & 1 \\
\hline Black & 1,504 & 0.18 & 0.39 & 0 & 1 & Black & 2,761 & 0.17 & 0.38 & 0 & 1 \\
\hline Hispanic & 1,503 & 0.16 & 0.36 & 0 & 1 & Hispanic & 2,761 & 0.27 & 0.44 & 0 & 1 \\
\hline BMI & 1,504 & 27.89 & 5.31 & 15.82 & 47.13 & & & & & & \\
\hline $\begin{array}{l}\text { Wife's } \\
\text { Characteristics }\end{array}$ & & & & & & $\begin{array}{c}\text { Wife's } \\
\text { Characteristics }\end{array}$ & & & & & \\
\hline Education & 1,504 & 12.96 & 1.97 & 6 & 20 & $\begin{array}{l}\text { Years of } \\
\text { Education }\end{array}$ & 2,861 & 11.3 & 3.67 & 0 & 17 \\
\hline Age & 1,504 & 21.85 & 2.38 & 18 & 40 & BMI & 2,650 & 27.42 & 6.2 & 15.1 & 58.4 \\
\hline $\begin{array}{l}\text { Maternal } \\
\text { years of } \\
\text { Education }\end{array}$ & 1,497 & 12.85 & 2.42 & 0 & 17 & Age & 2,873 & 48.32 & 17.95 & 17 & 90 \\
\hline White & 1,504 & 0.62 & 0.49 & 0 & 1 & White & 2,873 & 0.55 & 0.5 & 0 & 1 \\
\hline Black & 1,504 & 0.17 & 0.37 & 0 & 1 & Black & 2,873 & 0.17 & 0.38 & 0 & 1 \\
\hline Hispanic & 1,501 & 0.15 & 0.36 & 0 & 1 & Hispanic & 2,873 & 0.27 & 0.44 & 0 & 1 \\
\hline BMI & 1,504 & 28.06 & 7.08 & 16.91 & 49.25 & & & & & & \\
\hline
\end{tabular}


Table 2. SUR Regressions: Add Health Data

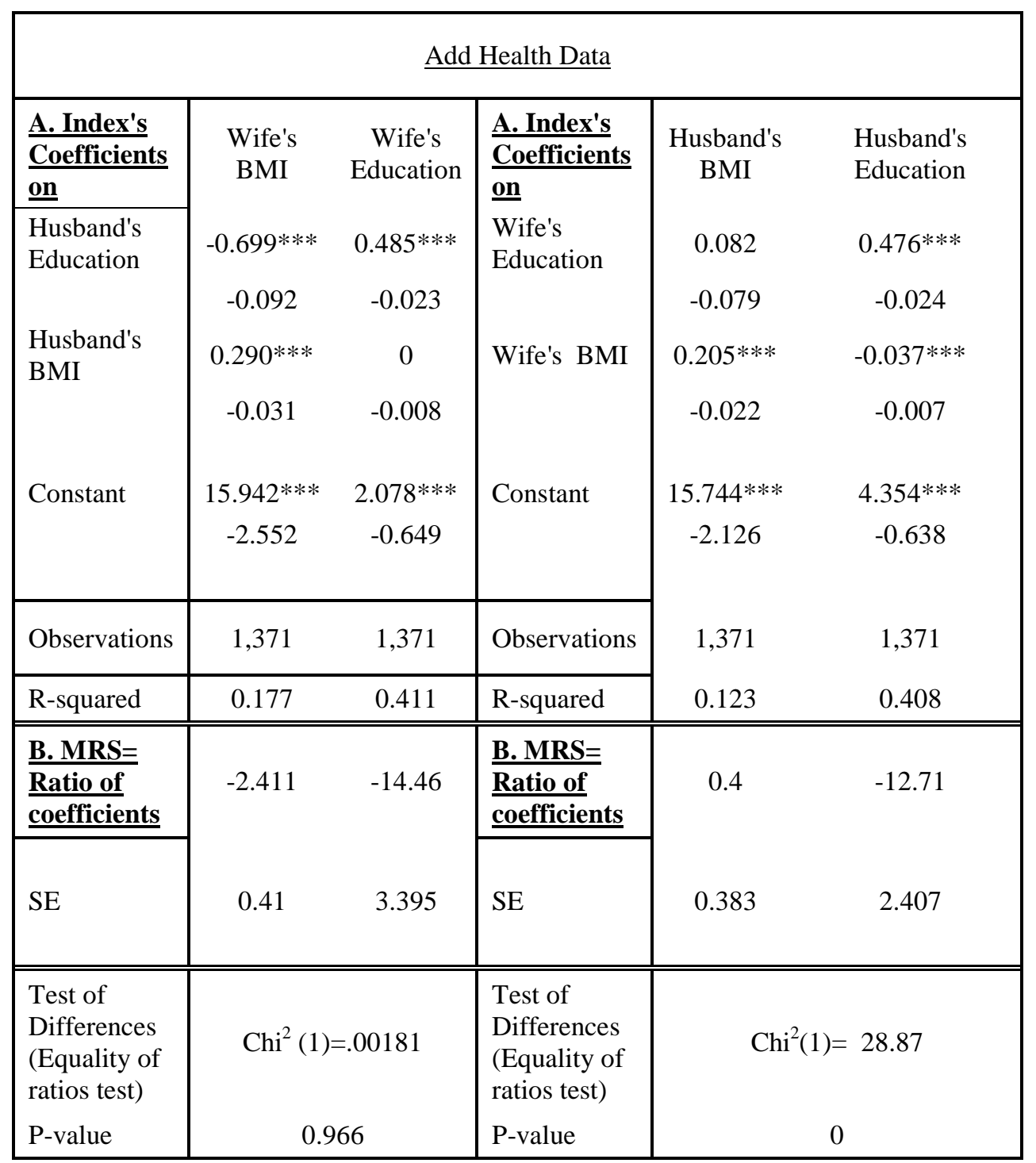

Note: Standard errors in are parentheses. Additional Controls: Age of husband and wife, maternal education level of husband and wife, race of husband and wife.

${ }^{*} \mathrm{p}$-value $<.1 .{ }^{* *} \mathrm{p}$-value $<.05 .{ }^{* * *} \mathrm{p}$-value $<.01$. 
Table 3. SUR Regressions: NHANES Data

\begin{tabular}{|c|c|c|c|c|c|}
\hline \multicolumn{3}{|c|}{ NHANES Data } & \multicolumn{3}{|c|}{ NHANES Data } \\
\hline $\begin{array}{l}\text { A. Index's } \\
\text { Coefficients on }\end{array}$ & $\begin{array}{l}\text { Wife's } \\
\text { BMI }\end{array}$ & $\begin{array}{c}\text { Wife's } \\
\text { Education }\end{array}$ & $\begin{array}{l}\frac{\text { A. Index's }}{\text { Coefficients }} \\
\underline{\text { on }}\end{array}$ & $\begin{array}{c}\text { Husband's } \\
\text { BMI }\end{array}$ & $\begin{array}{l}\text { Husband's } \\
\text { Education }\end{array}$ \\
\hline $\begin{array}{l}\text { Husband's } \\
\text { Education }\end{array}$ & $-0.206 * * *$ & $0.521^{* * *}$ & $\begin{array}{l}\text { Wife's } \\
\text { Education }\end{array}$ & 0.021 & $0.643^{* * *}$ \\
\hline & -0.034 & -0.015 & & -0.03 & -0.018 \\
\hline Husband's BMI & $0.251^{* * *}$ & -0.003 & Wife's BMI & $0.148^{* * *}$ & $-0.043 * * *$ \\
\hline & -0.026 & -0.011 & & -0.015 & -0.009 \\
\hline Constant & $\begin{array}{c}8.286 * * * \\
-0.73\end{array}$ & $\begin{array}{c}21.131 * * * \\
-1.177\end{array}$ & Constant & $\begin{array}{c}5.857 * * * \\
-0.684\end{array}$ & $\begin{array}{c}18.931 * * * \\
-1.583\end{array}$ \\
\hline Observations & 2,442 & 2,442 & Observations & 2,442 & 2,442 \\
\hline R-squared & 0.524 & 0.046 & R-squared & 0.527 & 0.107 \\
\hline $\begin{array}{l}\text { B. MRS= Ratio } \\
\text { of coefficients }\end{array}$ & -0.82 & -203.2 & $\begin{array}{l}\text { B. MRS= } \\
\text { Ratio of } \\
\text { coefficients }\end{array}$ & 0.145 & -14.98 \\
\hline SE & 0.159 & 877.6 & SE & 0.199 & 3.372 \\
\hline $\begin{array}{l}\text { Test of } \\
\text { Differences } \\
\text { (Equality of } \\
\text { ratios test) }\end{array}$ & $\operatorname{Chi}^{2}(1)=$ & 0.0532 & $\begin{array}{l}\text { Test of } \\
\text { Differences } \\
\text { (Equality of } \\
\text { ratios test) }\end{array}$ & $\operatorname{Chi}^{2}($ & $=20.05$ \\
\hline P-value & & & P-value & & 102 \\
\hline
\end{tabular}

Note: Standard errors in are parentheses. Additional Controls: Age of husband and wife, race of husband and wife.

${ }^{*} \mathrm{p}$-value $<.1 .{ }^{* *} \mathrm{p}$-value $<.05 .{ }^{* * *} \mathrm{p}$-value $<.01$. 


\section{References}

Bonke, J. and M. Browning (2009). "The distribution of financial well-being and income within the household." Review of Economics of the Household 7(1): 31-42.

Chiappori, P.-A., et al. (2012). "Fatter attraction: anthropometric and socioeconomic matching on the marriage market." Journal of Political Economy 120(4): 659-695.

Choo, E. and A. Siow (2006). "Who marries whom and why." Journal of Political Economy 114(1): 175-201.

Coe, N. B., et al. (2011). "Do Couples Self-Insure? The Effect of Informal Care on a Couple's Labor Supply." Center for Retirement Research at Boston College Working Paper 16.

Fagundes, C. P., et al. (2011). "Relationships and inflammation across the lifespan: Social developmental pathways to disease." Social and personality psychology compass 5(11): 891-903.

Falba, T. A. and J. L. Sindelar (2008). "Spousal concordance in health behavior change." Health services research 43(1p1): 96-116.

Galichon, A. and B. Salanié (2011). "Cupid's invisible hand: social surplus and identification in matching models." Available at SSRN 1804623.

Grundy, E. M. and C. Tomassini (2010). "Marital history, health and mortality among older men and women in England and Wales." BMC public health 10(1): 554.

Hitsch, G. J., et al. (2010). "Matching and sorting in online dating." The American Economic Review: 130-163.

Kohn, J. L. and S. L. Averett (2010). "Can’t We Just Live Together? New Evidence on the Effect of Relationship Status on Health." Journal of Family and Economic Issues: 118.

Kono, H., et al. (2011). "Does Marriage Work as a Savings Commitment Device?: Experimental Evidence from Vietnam." Unpublished Working Paper.

Oreffice, S. and C. Quintana-Domeque (2012). "Fat spouses and hours of work: are body and Pareto weights correlated?" IZA Journal of Labor Economics 1(1): 1-21. 